\title{
IMPLEMENTASI PENCATATAN KEUANGAN DIGITAL MENGGUNAKAN APLIKASI PINTERUSAHA.ID PADA SYMPHONY COFFEE BANDUNG
}

\author{
Mohamad Hadi Prasetyo \\ hadi.p@ekuitas.ac.id \\ Fia Dialysa \\ fdialysa@gmail.com \\ Resi Juariah Susanto \\ resi.juariah@gmail.com
}

\section{SEKOLAH TINGGI ILMU EKONOMI EKUITAS}

\begin{abstract}
ABSTRAK
Pengabdian kepada masyarakat ini bertujuan untuk melakukan pembenahan secara maksimal pada sistem keuangan manual dengan menggunakan aplikasi pencatatan keuangan dari pinterusaha.ai yang dibangun oleh wellcode.io pada Symphony Coffee Bandung. Program pengabdian kepada masyarakat ini berbentuk pelatihan dan juga pendampingan setelah adanya username dari pinterusaha.ai untuk pembekalan pencatatann keuangan secara digital kepada pelaku usaha. Pengabdian kepada masyarakat ini sebagai salah satu upaya untuk meningkatkan kemampuan dan keterampilan dalam mengatur pencatatan keuangan secara digital dan berujung pada pembenahan keuangan agar lebih jelas dalam mengetahui omzet yang diperoleh. Masalah yang sering dihadapi oleh pelaku usaha adalah dengan menggabungkan keuangan secara pribadi dengan pendapatan usaha yang diperolehnya. Hal ini sangat mempengaruhi perencanaan keuangan pada periode selanjutnya. Target luaran yang akan dicapai yaitu berupa publikasi dalam jurnal dan Peningkatan pemahaman dan keterampilan pelaku usaha. Hasil dari kegiatan pengabdian pada masyarakat ini ialah dengan adanya aplikasi pencatatan keuangan maka akan tercipta keseimbangan dari pencatatan keuangan pada bisnis tersebut. Adanya aplikasi ini, pelaku usaha akan dengan mudah merinci apa yang menjadi pengeluaran, berapa omzet yang didapat, dan akhirnya akan dapat melihat rekapan yang disini berarti sebagai laporan yang dapat digunakan oleh para pelaku usaha untuk menganalisis laporan keuangan secara sederhana demi tercipta strategi pengembangan kedepan.
\end{abstract}

Kata kunci: Aplikasi digital, Kedai Kopi Bandung, Pencatatan Keuangan.

\section{PENDAHULUAN}

Kota Bandung dapat dikatakan sebagai salah satu kota dengan tingkat inovasi yang tinggi, banyak sekali usaha kecil dan menengah yang dirintis oleh masyarakat Kota Bandung. Hal tersebut dibuktikan ketika Bandung berhasil mendapatkan gelar 
kota kreatif yang diberikan oleh Badan Ekonomi Kreatif (BEK). Kota Bandung juga dapat dikatakan tempat bagi mereka yang mencari pengalaman dalam wirausaha. Tidak jarang kita mendengar bahwa Kota Bandung merupakan surganya kuliner di antara kota-kota yang ada di Indonesia. Banyak sekali makanan dan minuman khas yang berasal dari kota berjulukan Kota Kembang ini. Dengan perkembangan industri kreatif yang ada di Kota Bandung, dapat diketahui dimulai dari industri fashion, sebagai salah satu sektor industri kreatif andalan Kota Bandung untuk meningkatkan perekonomian masyarakat. Hal tersebutlah yang menyebabkan Kota Bandung dikenal dengan julukan Paris Van Java. Namun, bukan hanya fashion saja satusatunya sektor industri kreatif di Kota Bandung. Industri kreatif lainnya yang berkontribusi signifikan terhadap perekonomian Kota Bandung, ialah subsektor kuliner.

Perkembangan subsektor kuliner di Kota Bandung selalu berkembang dari tahun ke tahun (BPS Kota Bandung, 2018), dapat dilihat perkembangan subsektor kuliner pada tahun 2016 menghasilkan kontribusi sebesar Rp. 179.836.984.000 dan meningkat pada tahun 2017 dengan kontribusi sebesar Rp. 197.184.696.000, terakhir pada tahun 2018 kembali mengalami peningkatan dengan kontribusi menjadi Rp. 215.006.989.000. Subsektor kuliner menjadi sesuatu yang potensial bagi para pengusaha di Kota Bandung. Baik pengusaha existing maupun para wirausaha baru.

Sudah sejak lama Kota Bandung dikenal dengan konsep wisata kulinernya. Dalam beberapa tahun belakangan ini salah satu bisnis kuliner yang memiliki perkembangan sangat potensial di Kota Bandung adalah usaha bisnis kedai kopi yang dapat dijumpai diseluruh pelosok Kota Bandung. Bagi para penikmat kopi sejatinya mereka akan mencari kopi berkualitas dengan bahan dasar dari biji kopi nusantara. Tetapi ada ada ceruk pasar lebih dalam yang dapat ditelusuri. Berdasarkan hasil observasi mandiri, bahwa ada pasar potensial dengan penyebutan "penikmat kopi senja", dimana artinya para penikmat kopi yang baru muncul dan biasanya di rentang usia 16-23 tahun. Inilah ceruk pasar yang sebenarnya menjadi dasar menjamurnya kedai kopi "dadakan" di Kota Bandung.

Dengan tingkat pertumbuhan rata-rata $37,1 \%$ selama 5 tahun terakhir (BPS Kota Bandung, 2018), menyebabkan tingkat persaingan menjadi lebih tinggi. Berbicara tentang persaingan, maka akan terjadi "perang" inovasi pada kedai-kedai kopi yang ada. Dapat dikatakan banyak inovasi yang terjadi baik itu merupakan inovasi produk ataupun inovasi pelayanan yang dapat dirasakan langsung konsumen. Artinya, ada suatu "keterpaksaan" melakukan inovasi pada subsektor kuliner ini yang tujuannya memberikan nilai tambah dan juga pengalaman baru bagi konsumen. Dengan banyaknya kedai kopi yang bermunculan, Symphony Coffee sebagai salah satu UMKM hadir dengan inovasi dan konsep berbeda. Menurut Tambunan (2012:11) Usaha Mikro Kecil dan Menengah (UMKM) adalah unit usaha produktif yang berdiri sendiri, yang dilakukan orang perorangan atau badan usaha di semua sektor ekonomi.

Menurut Mulyati (2016:2), fungsi dan peran Usaha Mikro Kecil dan Menengah (UMKM) sangat besar dalam kegiatan ekonomi masyarakat, meliputi (1) Penyediaan barang dan jasa (2) Penyerapan tenaga kerja (3) Pemerataan pendapatan nilai tambah bagi produk daerah (4) Peningkatan taraf hidup. Usaha Mikro Kecil dan Menengah mampu memberikan manfaat sosial yaitu pemerataan pendapatan terutama di negara-negara berkembang. Selain itu, usaha kecil juga menyediakan bahan baku atau jasa bagi usaha menengah dan besar, termasuk pemerintah lokal. (Mulyati, 2016).

Dengan persaingan yang terjadi, memaksa adanya inovasi pada bisnis, maka akan lahir suatu permasalahan. Dalam setiap bisnis, pasti ada permasalahan yang dihadapi. Keunggulan kompetitif merupakan suatu tujuan yang ingin dicapai 
para pelaku usaha dalam menjalankan usahanya, oleh karenanya inovasi merupakan suatu keharusan. Tetapi dalam perjalanannya memang tidak mudah. Hampir pada semua kedai kopi atau bahkan UMKM yang ada bahwa permasalahan yang kerap terjadi ialah permasalahan pada manajemen keuangan. Awalnya Symphony Coffee memliki kekurangan pada sistematika dalam melakukan pencatatan keuangan sehingga sulit dilihat mana yang menjadi biaya operasional tetap yang harus dikeluarkan dan juga mana yang menjadi biaya untuk membeli bahan baku kedepannya. Dari masalah ini juga muncul bahwa tidak adanya pemisahan antara dana pribadi sang pemilik dengan profit yang ada di bisnis tersebut. Tetapi hal tersebut sudah dapat diatasi berkat adanya pembenahan secara maksimal pada sistem keuangan manual yang terjadi selama ini.

\section{METODE KEGIATAN}

Metode pelaksanaan dalam program pengabdian pada masyarakat ini dapat dibagi menjadi 3 (tiga) bagian besar selain metode pelatihan dan juga pendampingan setelah adanya username dari pinterusaha.ai. Pertama-tama yang dilakukan ialah pendekatan masalah yang terjadi. Dimaksudkan disini ialah untuk menggambarkan permasalahan yang ada dan tim akan melakukan pengukuran masalah sesuai tingkatan prioritas. Dari hal ini akan lahir metode pendekatan yang ditawarkan untuk menyelesaikan persoalan mitra yaitu dengan dilakukannya diskusi antara tim Pogram Pengabdian Pada Masyarakat dengan pelaku usaha untuk lebih mengetahui kendala dan hambatan dalam menjalankan usaha. Hal tersebut agar tercipta solusi permasalahan yang ssuai dengan target program. Artinya disini haruslah ada pemahaman dan penyamaan persepsi antara tim dengan pelaku usaha.

Kedua, prosedur kerja program pengabdian pada masyarakat. Bahwa akan ada tim dari wellcode.io yang akan mempresentasikan aplikasi pinterusaha.ai kepada pelaku usaha. Setelah itu pelaku usaha akan diminta untuk trial dari sistem yang bersifat beta demi mendapatkan gambaran apabila memakai sistem aplikasi tersebut. Hal tersebut untuk mendapatkan keyakinan dari pelaku usaha dan pelaku usaha pun mendapat gambaran secara jelas terperinci apa yang akan mereka dapatkan pada saat nanti setelah mereka menggunakan sistem digital administrasi bisnis ini.

Fase ini pelaku usaha akan mendapat sistem digital administrasi bisnis secara beta untuk digunakan sebagai percobaan selama satu bulan. Dimana dalam satu bulan tersebut pelaku usaha juga diberikan pendampingan dari tim program pengabdian pada masyarakat. Pendampingan dimaksudkan agar pelaku usaha tidak kebingungan apa yang menjadi hak dan kewajiban dalam menggunakan aplikasi pinterusaha.ai tersebut.

Ketiga, rencana kegiatan dalam melakukan program pengabdian pada masyarakat yaitu implementasi sistem administrasi bisnis menggunakan aplikasi pinterusaha.ai. setelah sebulan diberikan versi beta dan dilakukan pendampingan tentang apa dan bagaimana aplikasi tersebut berjalan, maka pelaku usaha akan didaftarkan untuk mendapat username dan password untuk masuk ke sistem administrasi digital secara legal dan benarbenar sistem usaha sendiri. Akan ada biaya yang timbul disini dengan adanya pendaftaran pelaku usaha pada sistem administrasi digital dibawah pengembang wellcode.io.

Selanjutnya, tim dari wellcode.io dan tim program pengabdian pada masyarakat akan melakukan verifikasi dan gathering data dari pelaku usaha untuk disesuaikan dengan sistem yang ada. Data yang dibutuhkan disini ialah alur pencatatan keuangan dan pencatatan inventory yang dilakukan pelaku usaha. Tim program pengabdian pada masyarakat mendapat data ini dari pendampingan selama sebulan sebelumnya. Artinya akan ada penyesuaian data atau kebiasaan yang dilakukan pelaku 
usaha dengan sistem yang akan disematkan. Maksudnya disini ialah pelaku usaha pun akan mendapat kentungan bahwa sistem memang dibuat secara fleksibel sesuai dengan kebiasaan dari pelaku usaha. Intinya sistem pencatatan administrasi bisnis ini dibuat untuk mempemudah pelaku usaha. Metode pelaksanaan penyesuaian sistem administrasi bisnis pada pelaku usaha dapat dibagi menjadi introduction, perception, learning by doing, system habit, trial legal system, monitoring dan evaluation.

Introduction, tahap perkenalan dari developer kepada pelaku usaha dengan didampingi oleh tim program pengabdian pada masyarakat. Hal ini dilakukan demi memperkenalkan lebih jauh tentang sistem digital yang akan digunakan oleh para pelaku usaha. Perception, dimana tahap ini terjadi pada proses setelah mengenalkan sistem yang akan digunakan. Pada tahapan ini akan dilakukan persamaan persepsi antara developer, tim program pengabdian pada masyaraka, dan pelaku usaha. Dalam hal ini, pelaku usaha secara bebas akan mengemukakan apa yang diharapkan dari pelaku usaha dengan adamya sistem digital ini. Pelaku usaha juga bebas mengemukakan sesuatu yang bersifat fleksibel terhadap sistem yang akan digunakan.

Learning by doing, tahapan dimana pelaku usaha akan mendapat sistem digital versi beta yang bertujuan untuk membiasakan mereka dalam menggunakan sistem pada bisnis mereka sehari-hari. Jadi pelaku usaha akan mendapat sistem dalam hp mereka untuk dilakukan pencatatan administrasi bisnis yang mereka jalankan. System habit. Dengan adanya proses learning by doing, maka mereka dapat menentukan kira-kira menu apa saja yang mereka inginkan dalam sistem mereka nantinya. Tahapan ini akan dijembatani oleh tim program pengabdian pada masyarakat dengan developer terkait permintaan dari user yaitu pelaku usaha. Hal ini akan memudahkan pelaku usaha menyesuaikan apa yang akan mereka gunakan nantinya. Trial legal system, pada tahapan ini user atau pelaku usaha akan mendapatkan sistem yang sudah dirancang sesuai dengan permintaan user. Didapat dari tahapan learning by doing, maka pelaku usaha diharapkan dapat benar-benar menegerti apa yang menjadi kebutuhan mereka dengan menggunakan sistem digital administrasi bisnis ini.

Setelah semua itu, maka sistem secara legal akan diberikan kepada pelaku usaha. Disinilah adanya sinergi antara tim prorgam pengabdian pada masyarakat dengan pelaku usaha. Monitoring dan evaluation disini akan dilakukan pendampingan dengan pelaku usaha. Monitoring process dilakukan selama 3 bulan dengan evaluation selama 2 kali dalam sebulan. Dalam hal ini bila ada crack system maka langsung dilakukan pembenahan dan juga refresh server yang dilakukan developer. Dalam menggunakan sistem ini, pelaku usaha akan diberikan gratis maintenance selama 3 bulan berjalan. Selebihnya pelaku usaha akan dikenakan biaya maintenance yang dirasa tidak memberatkan pelaku usaha. Dalam keseluruhan tahapan ini dapat dilihat bahwa akan ada biaya pembuatan sistem, pendampingan selama versi beta sampai versi resminya, dan juga akan ada biaya pengadaan gawai bagi pelaku usaha.

\section{HASIL DAN LUARAN}

Proses implementasi sistem ini dilakukan terhadap staff yang memiliki tanggung jawab pada bagian pencatatan keuangan dan sejenisnya. Berikut beberapa dokumentasi terkait proses implementasi pencatatan keuangan secara digital di tempat pelaku usaha. 


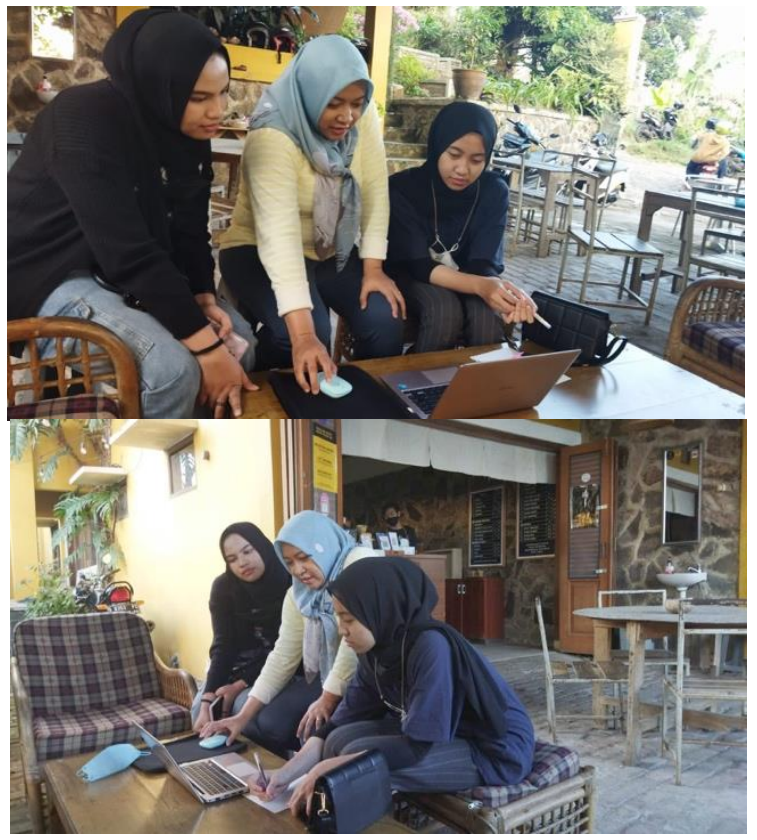

Gambar 1. Kegiatan Implementasi sistem pencatatan keuangan digital

Dengan aplikasi pencatatan keuangan berbasis web ini akan memudahkan pelaku usaha untuk melakukan pemeriksaan terhadap bagian keuangan baik itu penjualan maupun pembelian bahan baku dan sebagainya. Kegiatan bermula dari pembuatan akun percobaan untuk pelaku usaha, dan mencoba untuk menjalankan aplikasi tersebut selama beberapa bulan. Adanya aplikasi ini pelaku usaha akan dengan mudah merinci apa yang menjadi pengeluaran dan berapa jumlahnya serta berapa omzet yang dilakukan dalam hitungan harian yang dapat direkap kedalam bulanan dan tahunan. Inti dari sistem berbasis web disini ialah adanya rekapan dari penjualan secara bulanan dan tahunan yag dapat dirinci apa saja pengeluarannya, pemasukan, dan laba/ruginya.

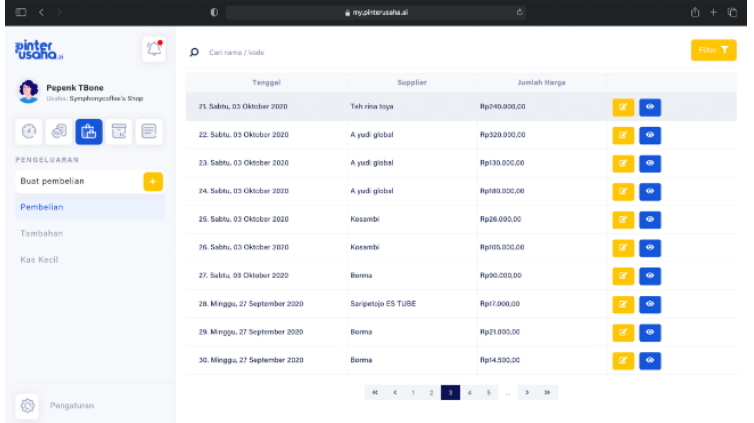

Gambar 2. Tampilan Sistem Untuk Pos Pengeluaran/Pembelian

Dengan adanya menu pos pengeluaran/pembelian, maka pelaku usaha dapat menghitung sampai sejauh mana pembelanjaan yang sudah dilakukan. Hal ini berguna untuk memproyeksi pengeluaranpengeluaran yang bersifat tetap maupun tidak tetap. Menu pengeluaran/pembelian disini berkaitan langsung dengan bahan baku yang terpakai selama ini. Bahan baku yang terpakai dapat dilihat pada menu inventory yang juga terlihat pada aplikasi berbasis web disini.

Pada gambar 2 sistem tersebut terlihat jelas bahwa untuk suatu produk tertentu telah memakai bahan baku dalam satuan sekian. Dari sini dapat dilihat bahwa kebutuhan bahan baku tiap produk dan sisa bahan baku yang dapat dipakai untuk membuat produk tersebut. Hal ini bermanfaat bagi pelaku usaha agar bisa menganalisis mana bahan baku yang cepat habis terhitung dari tanggal pembeliannya. Artinya, pelaku bisnis dapat merencanakan kira-kira kapan pembelian bahan baku tersebut dilakukan.

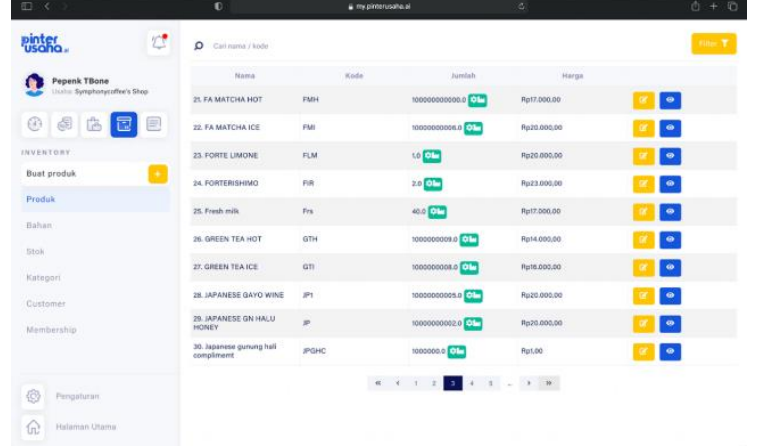

Gambar 3. Tampilan Sistem Menu Inventory 


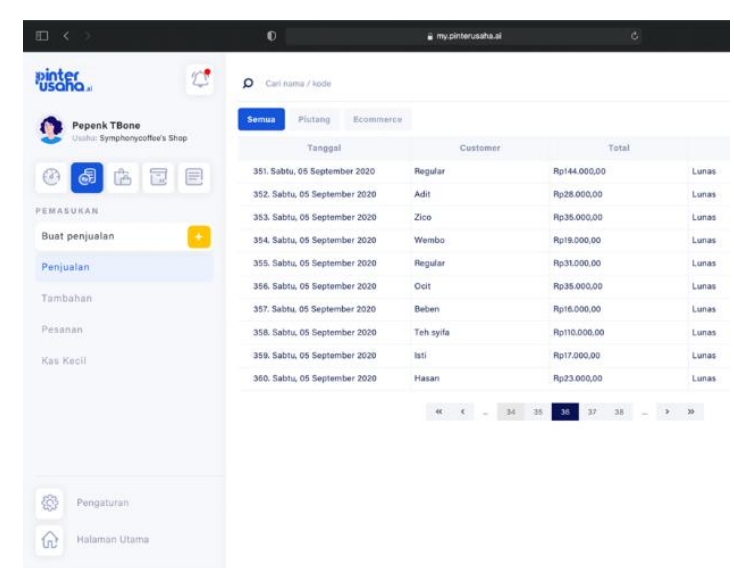

Gambar 4. Tampilan Sistem Menu Penjualan Harian

Dalam hal penjualan, pada sistem dapat dilihat mulai dari harian yang dapat dilihat juga secara mingguan ataupun bulanan. Gambar 3 terlihat lalu lintas penjualan dalam satuan harian. Terlihat juga ada nama customer pada sistem. Sebelumnya, para customer diminta nomor teleponnya untuk pengiriman nota/bill ke telepon genggamnya melalui aplikasi whatsapp. Selain dari menu tampilan harian, bisa di rekap juga kedalam menu bulanan maupun tahunan. Inti dari sistem berbasis web disini ialah adanya rekapan dari apa yang dilakukan selama sebulan seperti apa yang menjadi pengeluaran dan pemasukan serta biaya-biaya apa saja yang muncul. Hasil dari rekapan bersifat sebagai laporan yang dapat dianalisis oleh pelaku usaha. Berikut beberapa tampilan-tampilan dari sistem pada menu rekapan (laporan). Berikut beberapa tampilan dari sistem tentang menu rekapan bulanan, rekapan pengeluaran bulanan, dan laporan keuangan sederhana.

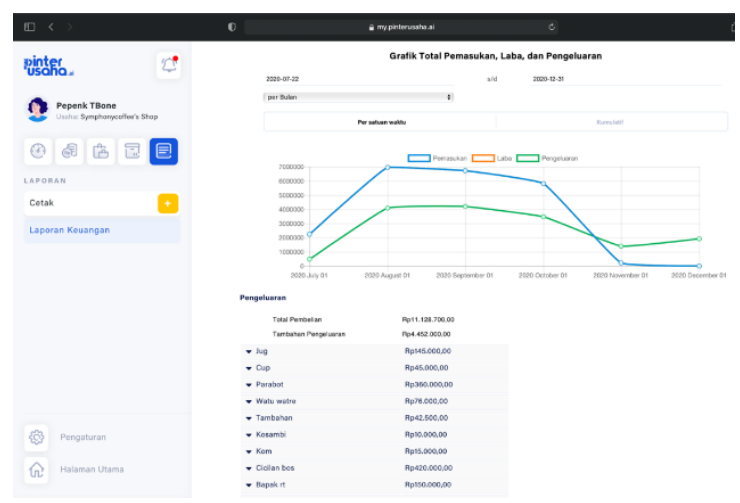

Gambar 5. Tampilan Sistem Menu Rekapan Bulanan

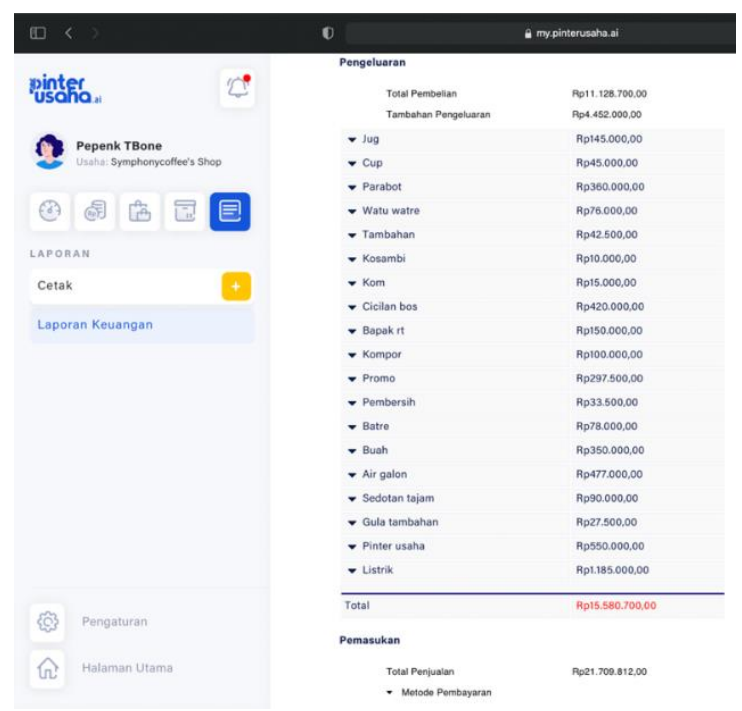

Gambar 6. Tampilan Sistem Menu Rekapan

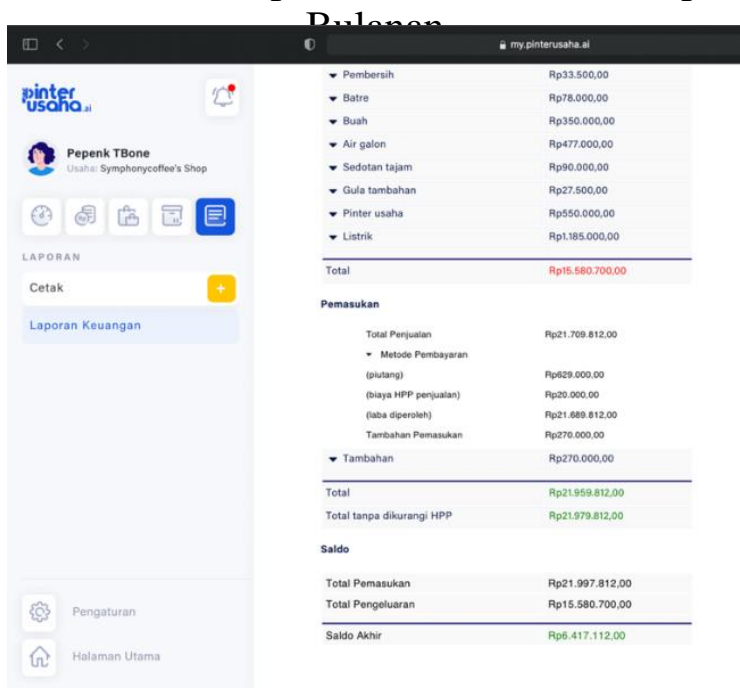

Gambar 7. Tampilan Sistem (laporan) Keuangan Sederhana 
Pelaku usaha dapat menggunakan laporan keuangan secara sederhana ini untuk menganalisis dan juga merumuskan strategi pengembangan bisnis kedepannya. Karena jelas terlihat dalam hal tersebut bahwa ada jumlah pengeluaran (biaya-biaya) yang dibandingkan dengan pemasukan selama sebulan. Maka akan terlihat langsung laba yang dihasilkan bulan tersebut.

\section{KESIMPULAN DAN SARAN}

Kesimpulan dari kegiatan ini ialah bahwa betapa pentingnya melakukan pencatatan keuangan yang terpisah baik dari keuangan pribadi maupun keuangan hasil usaha dan didukung pula dengan menggunakan teknologi yang semakin canggih dari sisi Financial Technology (Fintech) dimana dengan memanfaatkan teknologi yang ada akan lebih memudahkan para pelaku usaha dalam mengelola keuangan secara digital dan lebih tersusun dengan rapih. Dengan pencatatan keuangan yang baik maka akan menghasilkan pengambilan keputusan yang baik pula. Dimana dapat menjadi dasar pengambilan keputusan yang bersifat strategis baik jangka pendek, menengah maupun panjang.

\section{UCAPAN TERIMA KASIH}

Tim pengabdian mengucapkan Terima Kasih kepada STIE EKUITAS sebagai institusi yang sudah mendukung pelaksanaan program pengabdian kepada masyarakat ini. Juga kepada pelaku usaha, manajer Symphony Coffee Bapak Gesta dan Bapak Rizal dari pihak Wellcode.io yang memberikan bantuan dalam hal sistem yang user friendly.

\section{DAFTAR PUSTAKA}

Abyan, M.A. (2018), Konsep Penggunaan Financial Technology Dalam Membantu Masyarakat Sub Urban di Indonesia Dalam Melakukan Transaksi Finansial.
Dokumen BPS Kota Bandung (2018) tentang pertumbuhan rata-rata sektor kuliner.

Febri, I. P., Buntoro, G. A., \& Ariyadi, D. (2019). Pendampingan Usaha Ternak Lele Menuju Kemandirian Finansial Melalui Penerapan Sistem Akuntansi. Jurnal Dharma Bhakti Ekuitas, 3(2), 6-10.

(http:///www.fiskal.depkeu.go.id/kajian/thn 2004//Wibowo.pdf).

Mulyati, E. (2016), Asas Keseimbangan Pada Perjanjian Kredit Perbankan Dengan Nasabah Pelaku Kecil. Jurnal Bina Mulia Hukum. Vol.1.

Peraturan Bank Indonesia (PBI) Nomor 19/12/PBI/2017 tentang Penilaian Kualitas Aktiva Bank Umum.

Peraturan Otoritas Jasa Keuangan (POJK) nomor 77/POJK.01/2016 tentang Layanan Pinjam Meminjam Uang Berbasis Teknologi Informasi Rosen, S.H. (1995). Public Finance, 4th Edition. New York: McGraw Hill.

Sulindawati, E.L.N. (2017). Manajemen Keuangan sebagai dasar pengambilan keputusan bisnis. Cetakan Kesatu. Jakarta: PT. Raja Grafindo Persada.

Tambunan, T. (2012). Usaha Mikro Kecil dan Menengah di Indonesia: Isu-Isu Penting. Jakarta: LP3ES.

Tiebout, C. (2017). A Pure Theory of Local Government Expenditures, Journal of Political Economy, 1(2), 416-424.

Wibowo, T. (2004). "Potret Fiskal Daerah Sebelum dan Pada Era Desentralisasi”, Badan Pengkajian Fiskal, Departemen Keuangan, Republik Indonesia. 